\title{
Nieprzezroczystość ekfrazy: reprezentowanie, zapośredniczanie i przekład w opisach artefaktów
}

\begin{abstract}
Słodczyk Rozalia, Nieprzezroczystość ekfrazy: reprezentowanie, zapośredniczanie i przekład w opisach artefaktów [The non-transparency of ekphrasis: representation, mediation and translation in description of artefacts]. „Przestrzenie Teorii” 29. Poznań 2018, Adam Mickiewicz University Press, pp. 153-178. ISSN 1644-6763. DOI 10.14746/pt.2018.29.5.
\end{abstract}

The article concentrates on the non-transparency of ekphrasis, including the relevance - in the case of a full, in-depth analysis of particular ekphrasis - not only of the description but also of the artefact itself. The text reflects upon subjects rarely dealt with in ekphrasis research, such as on the meaning and relations of the concepts 'presentation' and 'representation'. There is a focus on the question of multi-layered mediation, which is related to this discourse figure: through language, through the viewer's perspective who writes about the work, through the reader themself, and also, or perhaps first and foremost, through the work itself. This all results in ekphrasis being treated as a representation of representation. This also gives rise to thoughts on the problem of translating the visual system to verbal and the issues related to this.

KEYWORDS: ekphrasis, presentation, representation, mediation, intersemiotic translation

W artykule zajmę się problemem niezprzezroczystości ekfrazy, lokalizującym tę figurę dyskursu na mapie zagadnień literaturoznawczych i teoretyczno-literackich, a raczej na pewnym wycinku tej mapy. Nie będę tu bowiem odnosić się do innych, może bardziej podstawowych kwestii, w jakie uwikłana jest problematyka relacji werbalno-wizualnych (podejmowanych między innymi w nurcie komparatystycznym), ani nie skupię się na możliwych rozumieniach pojęcia ekfrazy i historii tej formy, czym zajmuję się gdzie indziej. Chciałabym skoncentrować się na mniej oczywistych i często pomijanych przy okazji pisania o ekfrazie tematach, niezbędnych jednak do zrozumienia złożoności tej formy wypowiedzi. W ten sposób przekonujemy się, że jest to zjawisko tyleż atrakcyjne, co skomplikowane i uwikłane w sieć innych problemów.

\section{Prezentacja versus reprezentacja}

Ekfrazę często definiuje się jako słowną reprezentację dzieła sztuki. Komentarza wobec tego wymaga pojawiająca się konfuzja terminologiczna $\mathrm{w}$ dyskursie intersemiotycznym, wynikająca z pomieszania nietożsamych 
pojęć prezentacja, reprezentacja, przedstawienie, pomimo że już kilku badaczy podkreślało odrębność tych terminów. W literaturoznawstwie polskim najwyraźniej chyba uczynił to Michał Paweł Markowski, choć temat podją jako pierwszy Ryszard Nycz, który o reprezentacji pisał, że jest „tym poprzez co, tym dzięki czemu uznajemy to, co jest poza. Jest więc zastępowaniem

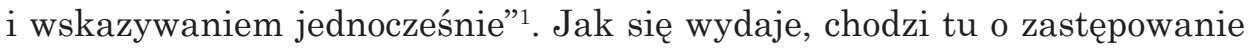
w specyficznym znaczeniu, to znaczy nie bycie zamiast czegoś i jednocześnie bycie takim jak to, zamiast czego się jest, ale odnoszenie do czegoś i bycie tego namiastka - w rezultacie nie bycie sobowtórowym ekwiwalentem, ale autonomicznym, osobnym przedmiotem. Tak rozumiana reprezentacja uobecnia to, co przedstawia, gdyż prezentuje (pokazuje, wskazuje na) dany przedmiot (jak ujmuje to Markowski: „bez odniesienia do reprezentowanej rzeczy byłaby zawieszona w semantycznej próżni”'), ale też odobecnia reprezentowany (zastępowany) przedmiot (ponieważ znak, czy to językowy, czy wizualny, czy inny, jest zamiast przedstawianej rzeczy) ${ }^{3}$. Można zatem wyodrębnić dwa aspekty reprezentacji: 1) substytucja, zastępowanie tego, co nieobecne, czymś obecnym, bycie zamiast czegoś, a zarazem 2) uobecnianie tego, co poza reprezentacja, przywoływanie i wystawianie na widok. Temu

${ }^{1}$ R. Nycz, Tezy o mimetyczności, [w:] tegoż, Tekstowy świat. Poststrukturalizm a wiedza o literaturze, Warszawa 1993, s. 249.

${ }^{2}$ M.P Markowski, Pragnienie obecności. Filozofie reprezentacji od Platona do Kartezjusza, Gdańsk 1999, s. 10.

${ }^{3} \mathrm{~W}$ tym miejscu warto przywołać łaciński źródłosłów pojęć prezentacji i reprezentacji: praesento, praesentare - to stawiać przed (oczami), pokazywać, wystawiać (na widok), z kolei repraesento, repraesentare - to pokazywać, wystawiać (na pokaz), manifestować (zmysłom), czynić obecnym dla umysłu, ale też przywrócić (to co stracone, martwe), ożywić, służyć jako ekwiwalent, reprezentować - być w miejsce czegoś albo kogoś czy wreszcie płacić od razu, w gotowiźnie, wykonywać natychmiast, czynić zaraz dostępnym. W samym słowie „reprezentacja” zawarty jest więc modus uobecniania (przywracanie, ożywianie) i zastępowania (bycie w miejsce czegoś lub kogoś). Por. odpowiednie hasła w: Oxford Latin Dictionary, ed. by P.G.W. Glare et al., Oxford 1968. Kwestie te zostały pierwotnie nazwane i oddzielone wcześniej i nie na gruncie polskim - wiele miejsca poświęca im np. francuski filozof i krytyk Louis Marin. W 1978 roku pisał o przedstawianiu, które znaczy „nadawać obecność nieobecnemu przedmiotowi, uobecniać go jako nieobecny”; L. Marin, Przedstawienie i pozór, przeł. P. Mościcki, [w:] tegoż, O przedstawieniu, Gdańsk 2011, s. 363. Szczególnie wiele miejsca poświęcił temu zagadnieniu w wykładzie Mimesis et description en peinture wygłoszonym w czasie First International Conference On Word \& Image, Vrije Universiteit Amsterdam, 21-25 April 1987. Marin odnosi tu do słownika Furetière’a z końca XVII wieku i definicji czasownika représenter (w polskim tłumaczeniu oddanego jako „przedstawiać): „Przedstawiać znaczy z jednej strony zastępować to, co obecne, tym, co nieobecne [...]; to substytucja, która jest uregulowana (natura lub konwencja) przez ekonomię mimetyczna - właśnie to postulowane podobieństwo obecnego i nieobecnego pozwala na zabieg zamiany. Lecz jest jeszcze inne znaczenie, według którego przedstawiać oznacza pokazać, ukazywać, podkreślać, jednym słowem: prezentować obecność”; L. Marin, Mimesis i opis, przeł. E.M. Wierzbowska, [w:] tegoż, O przedstawieniu..., s. 300. 
podziałowi towarzyszą dwa modele reprezentacji, koncentrujące się odpowiednio na jednym z aspektów - semiotyczny i mimetyczny (wynikające ze sporu o to, do czego odsyła reprezentacja: do językowego znaczenia czy do rzeczywistości) ${ }^{4}$.

Można jeszcze inaczej spojrzeć na te dwie strony reprezentacji, jak czyni to Markowski. W jego ujęciu dwoistość czy bipolarność reprezentacji polegałaby na tym, że „Jest ona tyleż zastępowaniem (re-prezentacja) rzeczy przez znak, co jej uobecnianiem (przed-stawianiem) w umyśle" ${ }^{\text {. Uobecnia- }}$ nie nie byłoby więc wiązane ze wskazywaniem na rzecz poprzez podobieństwo do niej, ale z myślowym i imaginacyjnym uobecnianiem wyobrażenia/ wizji rzeczy. Zgodnie z takim tokiem myślenia można wyciagnąć wniosek, że binarny charakter pojęcia nie wyraża jakiejś aporii w nim zawartej, ale dwupoziomowość procesu, który rządzi mechanizmem reprezentacji. I tak, na poziomie formalno-treściowym reprezentacja odobecnia przedstawiane, gdyż zastępuje jeden system znakowy innym (np. wizualny - werbalnym) i przedstawiane nie istnieje już $\mathrm{w}$ przetworzeniu tak jak przed nim czy poza nim; z kolei na poziomie konceptualno-wyobraźniowym reprezentacja uobecnia, gdyż przyswaja przedstawiane, nadaje mu kształt pojęciowy i konkretność, pozbawia obcości.

Terminy prezentacji i reprezentacji odróżnia też np. Seweryna Wysłouch, która łączy prezentację z uobecnieniem, a reprezentację z osłabianiem uobec-

${ }^{4}$ Por. M.P. Markowski, O reprezentacji, [w:] Kulturowa teoria literatury. Gtówne pojęcia i problemy, red. M.P. Markowski, R. Nycz, Kraków 2010, s. 287-333. Z pierwszym przypadkiem (modelem semiotycznym) łączy się koncepcja znaku de Saussure’a, jako że relacje między znaczącym a znaczonym zachodzą wewnątrz języka, a nie między językiem a rzeczywistością„reprezentacja jest zamiast rzeczywistości”; tamże, s. 295. O reprezentacji tak pojmowanej (bycie zamiast, w miejsce czegoś) jako fundamentalnym od starożytności (z kluczowymi dziełami: Poetyka Arystotelesa i X księgą Państwa Platona) koncepcie dla estetyki i semiotyki pisze też między innymi W.J.T. Mitchell. Semiotycy wyróżniają trzy przypadki relacji między tym, co reprezentowane, a tym, co reprezentujace, z uwzględnieniem tego, za pomoca czego się reprezentuje: 1) reprezentacja ikoniczna (oparta na podobieństwie) - w przypadku obra$\mathrm{zu}, 2$ ) reprezentacja symboliczna (ustanowiona arbitralną decyzja) - w przypadku języka, 3) reprezentacja indeksowa (wskaźnikowa, od ang. index) - oparta na związku przyczynowo-skutkowym czy przyległościowym między zjawiskami i rzeczami. Por. Ch.S. Peirce, The icon, index and symbol, [w:] Collected Papers of Charles Sanders Peirce. Vol. II. Element of Logics, ed. by Ch. Hartshorne and P. Weiss, Cambridge (MA) 1931, s. 274-309; W.J.T. Mitchell, Representation, [w:] Critical Terms for Literary Study, ed. by F. Lentricchia, T. McLaughlin, Chicago 2010, s. 11-22. Por też U. Eco, Teoria semiotyki, przekł. M. Czerwiński, Kraków 2009.

${ }^{5}$ M.P. Markowski, Pragnienie obecności..., s. 11. Badacz odnosi tu do rozumienia reprezentacji (re-praesentatio) jako ponownej prezentacji, uobecnienie rzeczy przez znak (co chyba trzeba rozumieć w ten sposób, że dana rzecz sama się prezentuje, wskazuje na siebie, a ponownie dochodzi do tego za pośrednictwem innego niż sama ta rzecz medium - znaku). Z kolei przedstawienie (Vorstellung) to wyobrażenie, „ustanowienie przedmiotu przez podmiot za pomocą umysłowej reprezentacji, czyli idei”. 
nienia ${ }^{6}$, oba zaś przypadki konfrontuje, odnosząc się do ekfrazy. Oddziela mianowicie ekfrazę starożytna, jej zdaniem uosabianą w dziele Filostrata, od ekfrazy dzisiejszej, która nie prezentuje, nie uobecnia, często tworzy „syntetyczny" model tego, do czego się odnosi, przekształca i upraszcza przedmiot referencji, w rezultacie, zdaniem badaczki, nie prezentuje przedmiotu, ale go tylko reprezentuje ${ }^{7}$. Nie jest jednak jasne, dlaczego faza konceptualizacji danych wizualnych przez podmiot, który postrzega znaki ikoniczne i chce je przełożyć na znaki werbalne (Wysłouch odnosi się do kognitywistycznej koncepcji „ujęzykowienia” ikoniczności), miałaby rozpuszczać konkretność przedmiotu, czynić go rachitycznym, pozbawiać materialności przez zamienianie go w znak i zastępowanie oryginału. Przedstawienie malarskie nie jest prawdziwą obecnością danych obiektów, ale ich reprezentacją znakowa, w niej samej znajdujemy stronę uobecniającą i stronę zastępującą. Wydaje się, że o ile prezentacja może istnieć samodzielnie (coś samo się prezentuje, pokazuje, np. jakiś przedmiot), reprezentacja pociaga za sobą modus prezentacji - wskazywania na obiekt, czynienia go obecnym tu i teraz, a zatem prezentacja jest z nią niezbywalnie połączona. Jednocześnie tak pojmowana prezentacja nie jest przezroczysta, scil. także zapośrednicza, sama bowiem posiada jakaś materialność, formę (np. dany tekst, który traktuje o obrazie); można ją ewentualnie tak rozumieć, że bardziej chciałaby odsyłać do owego przedmiotu odniesienia niż do siebie, i wobec tego argumentować, że bardziej uobecnia przedmiot, ale przecież nie ożywia go, nie przywraca jego istnienia, ale wskazuje na niego, stawia go przed oczami. Stanowi jakby pierwszy krok reprezentacji, która ów przedmiot chce wystawić na pokaz, ale przez bycie w jego miejsce, przez zastępowanie go w innym medium. Wydaje się, że można zaproponować interpretowanie prezentacji jako zjawiska deiktycznego, a reprezentacji - jako fenomenu epideiktycznego ${ }^{8}$.

${ }^{6}$ Por. S. Wysłouch, Ekfraza czy przektad intersemiotyczny?, [w:] Ruchome granice literatury. Wkregu teorii kulturowej, pod. red. S. Wysłouch, B. Przymuszały, Warszawa 2009, s. 48-64.

${ }^{7}$ Por. między innymi wniosek badaczki: „Osłabienie przedmiotowości musi pociagać za sobą osłabienie prezentacji. [...] Redukcja i syntetyzacja opisu zmieniają prezentację w reprezentację, a tym samym zmieniają status przedmiotu, który staje się znakiem i funkcjonuje jako znak kultury, wobec którego podmiot mówiący przyjmuje postawę oceniającego i interpretatora”; tamże, s. 62 , 63. Wydaje się, że następuje tu pomieszanie różnych przypadków odniesienia do jednego lub do kilku dzieł sztuki, opisywania jednego dzieła lub fragmentów kilku dzieł, opisywania pełnego, klasycznego albo redukującego i syntetyzującego (przez wybiórczy i swobodny autorski wybór). Przedmiot odniesienia zawsze jednak istnieje jako konkretna materia, choć reprezentująca za pomoca znaków, a jeśli nie istnieje, to zgodnie z moim rozumieniem ekfrazy, nie mówimy w ogóle o ekfrazie.

${ }^{8}$ Odróżnienie to znajduje swoją podstawę w znaczeniu greckich terminów: deiktikós pokazujący, wykazujący (dowodzący), wskazujący (wyjaśniający); epideiktikós - ukazujący, wystawiający na pokaz, obrazujący, efektownie ilustrujący. Por. odpowiednie hasła w: Glossary of Greek Rhetorical Terms Connected to Methods of Argumentation, Figures And Tropes From 


\section{Ekfraza jako reprezentacja reprezentacji}

Ze względu na problematykę relacji werbalno-wizualnych ogniskujacych się w ekfrazie uwagi wymaga również ogólniejsza kwestia rozdzielenia prezentacji i reprezentacji malarskiej ${ }^{9}$ od prezentacji i reprezentacji słownej. Mateusz Salwa zaproponował w tym zakresie odróżnienie obrazu, który prezentuje, daje przedmiot do oglądania, od tego, który reprezentuje, pokazuje ten przedmiot ${ }^{10}$. Prezentacja zakładałaby bezpośredniość przekazu, dawania rzeczy samej (jak w trompe l'oeil), reprezentacja natomiast pośredniość - obraz tylko odnosi do przedmiotu, jest jego swoistym zastępnikiem. Jeśli chodzi o reprezentację i prezentację, należy jeszcze dodać, że uwikłane w relacje moga być nie tylko tekst i rzeczywistość pozatekstowa (jak obraz i rzeczywistość pozaobrazowa), ale też tekst i inny tekst, tekst i obraz, obraz i obraz etc. (a więc formy należące do tego samego albo innego medium). Otóż w tekście (a też w obrazie) zasadniczo stykamy się z reprezentacją zbudowaną na relacji dwustopniowej - wypowiedź słowna (a także przedstawienie malarskie) i rzeczywistość, do której słowo (obraz) odnosi, którą ponownie prezentuje/re-prezentuje i uobecnia. Sytuacja zmienia się, jeśli przedmiotem odniesienia staje się coś, co nie jest naturalnym obiektem, ale dziełem artystycznym, które samo reprezentuje - jedna forma twórczości odnosi wówczas do innej, a w efekcie powstaje reprezentacja reprezentacji (przypadek ekfrazy - stąd nośna definicja ekfrazy Heffernana „verbal representation of visual representation"11). Opis wyzwala pewne idee na

Anaximenes to Quintilian, ed. R.D. Anderson Jr., Leuven 2000. Co ważne, termin ten stosuje Michael Baxandall, kiedy pisze o renesansowych ekfrazach krytyków sztuki: „The ekphrases describe qualities of detailed lifelikeness, of physiognomic expressiveness, of variety, and they describe this in an affirmative form, for ekphrasis is a device of epideictic, the rhetoric of praise or blame: there are no neutral ekphrases" (wyróżnienie moje); M. Baxandall, Giotto and the Orators. Humanist Observers of Painting in Italy and the Discovery of Pictorial Composition, Oxford 1971, s. 87. Z kolei Gottfried Boehm podkreśla znaczenie pokazywania, które łączy z naocznością: „Kto pokazuje, uwydatnia coś, uwidacznia, wyodrębnia coś w naocznym umiejscowieniu. [...] Gest pokazywania [...] prowadzi ku czemuś, wytycza nowy szlak spojrzeniu, i robi to ze szczególną uwagą. Poznawcza siła deixis przejawia się najdobitniej w tym, że pokazany przedmiot się ukazuje"; G. Boehm, Opis obrazu. O granicach obrazu i języka, przeł. M. Łukasiewicz, [w:] tegoż, O obrazach i widzeniu. Antologia tekstów, red. D. Kołacka, Kraków 2014, s. 141.

${ }^{9}$ Por. badania z zakresu filozofii sztuki: D. Summers, Representation, [w:] Critical Terms for Art History, ed. by R.S. Nelson, R. Shiff, Chicago-London 1996, s. 3-16; rozdz. Art and Representation, [w:] N. Carroll, Philosophy of Art. A contemporary Introduction, LondonNew York 2002, s. 18-57; rozdz. Representation, imitation, and resemblance, [w:] R. Eldridge, An Introduction to the Philosophy of Art, Cambridge 2003, s. 25-46.

${ }^{10}$ Por. M. Salwa, Iluzja w malarstwie. Próba filozoficznej interpretacji, Kraków 2010, s. 114.

${ }^{11}$ J.A.W. Heffernan, Museum of Words. The Poetics of Ekphrasis from Homer to Ashbery, Chicago 1993, s. 3. Klasyczna ekfraza miała tego dokonywać za pomocą unaoczniającego 
temat plastycznego modelu, uobecnia więc go, ale jednocześnie zastępuje go w innym systemie znakowym, zatem unieobecnia ${ }^{12}$, co wiąże się z dystansem istniejącym między przedmiotem odniesienia (artefaktem) a jego reprezentacja.

Temat ekfrazy jako reprezentacji reprezentacji podjęli też inni badacze ekfrazy. Tamar Yacobi utrzymuje, że w ekfrazie zarówno to, co reprezentowane (dzieło sztuki), jak i to, co reprezentujace (tekst literacki), stanowi reprezentację pewnego przedmiotu. Badaczka jest zdania, że np. Oda do urny greckiej Keatsa nie reprezentuje bezpośrednio, ale re-prezentuje to, co urna bezpośrednio reprezentuje: „Jak każdy cytat, ekfraza łączy nie mniej niż trzy, raczej niż dwa, obszary: jeden, z pierwszego poziomu, ściśle 'reprezentowane', jeden z drugiego poziomu, 'reprezentujace' w trybie wizualnym, jeden z trzeciego poziomu, 're-prezentujące' w wypowiedzi językowej" ${ }^{13}$.

Przykład z urną jawi się jednak jako przewrotny, gdyż jest ona potencjalnie naturalnym przedmiotem (funkcjonalnym), na którym dodatkowo coś przedstawiono (i przez to staje się dziełem sztuki); izraelska uczona chce zaakcentować fakt, że obcujemy tu z trzyczęściowym łańcuchem mimesis, w którym dzieło sztuki przedstawia coś, co istnieje poza nim, a samo jest przedstawiane przez inne medium. Podobnymi obserwacjami na temat dwustopniowości (i trójelementowości) reprezentacji w ekfrazie dzieli się Michael Riffaterre, formułując sąd:

Jako że tekst ekfrastyczny reprezentuje za pomocą słów reprezentację plastyczna, mimesis jest podwójna. Jednak jest także iluzoryczna, ponieważ albo jej przedmiot jest wyimaginowany, albo opis przedstawia [dosł. daje do zobaczenia] tylko inter-

dzieło sztuki opisu, współczesna zaś raczej za pomocą tekstu o charakterze interpretacyjnym, refleksyjnym, wspomnieniowym, w formie subiektywnego komentarza albo skojarzenia.

${ }^{12} \mathrm{O}$ innym jeszcze rozumieniu nieobecności dzieła w tekście pisze Gary Shapiro w artykule The absent image: ekphrasis and the 'infinite relation' of translation, „Journal of Visual Culture" 2007, Vol. 6, No. 1, s. 13-24. Odnosi się on do przerwy, odstępu, różnicy (ang. gap) między tym, co jest widziane, a tym, co może zostać powiedziane. Zauważa, że historycznie ekfraza zrodziła się z pragnienia opisania danego dzieła właśnie dlatego, że nie było ono widzialne dla odbiorcy. Chodzi tu z jednej strony o nieistnienie oryginalnego dzieła zniszczonego przez czas i historię albo wymyślonego przez piszącego bądź o niedostępność tak oryginału, jak jakieś formy jego kopii (problem braku reprodukcji - jeszcze w XVIII wieku piszący formułowali refleksję, że ich opisy muszą funkcjonować pod nieobecność obrazu). $\mathrm{Z}$ drugiej strony chodzi też o metaforyczną absencję, co znajduje wyraz w pismach francuskich poststrukturalistów, których przywołuje badacz: ten, kto pisze o dziele, ogarnia je zaprojektowanym przez siebie znaczeniem, nie ma jednego głosu komentarza i interpretacji, $\mathrm{w}$ tym sensie nie istnieje dzieło podporządkowane słowu, język nie ma pierwszeństwa przez obrazem językowi.

${ }^{13}$ T. Yacobi, The ekphrastic model: forms and functions, [w:] Pictures into Words. Theoretical and Descriptive Approaches to Ekphrasis, ed. by V. Robillard, E. Jongeneel, Amsterdam 1998, s. 22. 
pretację podyktowaną w mniejszym stopniu przez przedmiot, realny czy fikcyjny, niż przez jego rolę w kontekście literackim ${ }^{14}$.

Badacz jest przeświadczony, że owa „podwójna mimesis, reprezentacja reprezentacji, jest bliższa iluzji referencjalnej ${ }^{15}$ niż autentycznej reprodukcji przedmiotu"16. W analogicznym tonie komentuje problem stosunku słowa do obrazu w ekfrazie Mitchell, kiedy konstatuje, że ekfrastyczne spotkanie w języku jest „czysto metaforyczne” (,purely figurative”) - to, co wizualne (obraz), nie może zostać pokazane, jest silna nieobecnościa albo fikcyjną obecnością: „To wymaganie figuratywności [wizualnego przedstawienia] nakłada specyficzną presję na gatunek ekfrazy, dlatego że to, co inne względem tekstu [obraz], musi pozostać kompletnie obce; nigdy nie może być obecne, ale musi być przywołane jako silna nieobecność albo fikcyjna, figuralna obecność"17. To samo twierdzi wreszcie John Hollander, nadajacy tylko swojej obserwacji inne uzasadnienie. Spostrzega, że każdy zaprezentowany w ekfrazie obraz jest swoistą werbalną fikcją (bez względu na to, czy ekfrazy odnoszą do prawdziwych czy nierealnych dzieł sztuki) ${ }^{18}$. Ekfraza bowiem to nie kopia artefaktu, ale zapisana subiektywna wizja obrazu, jaką ma dany piszący, który stosuje określone środki retoryczne i literackie, aby uzyskać zamierzony efekt.

Trzeba jeszcze dodać, że odniesienie do desygnatu z realnego świata w przypadku ekfrazy jawi się jako konieczne i potrzebne; wychodzi się tu od innej koncepcji znaku, a mianowicie nie de Saussure'a, ale Pierce'a - takiej, w której występuje trzeci element, a mianowicie odniesienie do rzeczywistości pozatekstowej. W pewnym sensie ekfrazę charakteryzowałaby swoista zadana przezroczystość słowa. Warto zatrzymać się na tej kwestii.

${ }^{14}$ M. Riffaterre, L'illusion d'ekphrasis, [w:] La pensée de l'image. Signification et figuration dans le texte et dans la peinture, sous le direction de G. Mathieu-Castellani, Saint-Denis 1994, s. 211.

${ }^{15}$ Por. M. Riffaterre, The referential fallacy, „Columbia Review”, 1978, Vol. 57, No. 2, s. 21-35 (wersja francuska: L'illusion référentielle, trad. P. Zoberman, [w:] R. Barthes et al., Littérature et réalité, Paris 1982, s. 91-118). Iluzją referencjalną (lub błędem referencjalnym) nazywa się albo przekonanie, że signifiant znaku koniecznie musi mieć swój desygnat (referent) w realnym świecie, albo twierdzenie, że znaczenie znaku zawiera się w samym desygnacie. Takie założenie wydaje się jednak fałszywe; istnieja signifianty (jak np. spójniki w języku), które nie mają żadnej denotacji w świecie pozajęzykowym. Poza tym na teksty możemy patrzeć jako na odnoszace się do innych tekstów, a nie do świata realnego.

${ }^{16}$ M. Riffaterre, L'illusion d'ekphrasis..., s. 211.

${ }^{17}$ W.J.T. Mitchell, Ekphrasis and the other, [w:] tegoż, Picture Theory. Essays on Verbal and Visual Representation, Chicago 1994, s. 158.

18 J. Hollander, The Gazer's Spirit: Poems Speaking to Silent Works of Art, Chicago 1995, s. 32. 
Od odbiorcy ekfrazy konkretne dzieło sztuki wymaga bądź zwizualizowania go sobie imaginacyjnie, bądź wyobraźniowego przypomnienia (jeśli je znamy), bądź przywołania reprodukcji (ewentualnie spotkania z oryginałem). Zachodzi więc potrzeba wyjścia poza tekst i konfrontacji z dziełem wizualnym. Obiekty, zdarzenia, postaci zwyczajne - to znaczy mające ogólne pierwowzory w rzeczywistości pozatekstowej, ale jako twory tekstowe niezależne od świata zewnętrznego, stworzone wyobraźnią piszącego - nie zmuszają nas do takiej komparacji świata tekstowego z zewnętrznym uniwersum, wydają się spójne bez odsyłania do tego, co poza tekstem. W ekfrazie gra sensu nie odbywa się już tylko w sferze znaczaccego i znaczonego ${ }^{19}$, ale przenosi się na poziom desygnatu; w tym znaczeniu ekfraza byłaby silniej powiązana ze światem pozatekstowym. Przedmiot referencji, to znaczy dzieło sztuki, jest niezbędnym przypisem czy załącznikiem do danej wypowiedzi językowej, którą nazwiemy ekfrazą. Jednocześnie zdaje się mieć inny status niż zwykłe przedmioty z rzeczywistości pozajęzykowej - sam jest tworem artystycznym, i pozostaje w obszarze konstruktów znakowych. W ekfrazie plastyczny artefakt i poświęcony mu tekst tworzą dopełniająca się całość. Obraz może istnieć bez ekfrazy albo hypotypozy, ale one bez obrazu nie (pomijając przypadek tzw. ekfraz fikcyjnych, imaginacyjnych); pełnego blasku nabieraja, kiedy wzajemnie się naświetlają. Ten układ przywodzi na myśl, tak z punktu widzenia struktury, jak znaczenia, formę malarskiego pendantu ${ }^{20}$, jako że obraz jawi się jako potrzebne dopełnienie, uzupełnienie takich form jak ekfraza. Nie tylko jest ich źródłem i podstawa, ale też elementem niezbędnym do pełnego ich pojęcia, zinterpretowania; $w$ tym sensie

${ }^{19}$ Marin pisał o uchwytywaniu sensu w czytaniu jako o przechodzeniu od znaków graficznych do ich znaczenia: znaki muszą się stać prześwitujące, jakby zniknąć z oczu czytelnika - „W przeciwnym razie zatrzymuje się on i skupia jedynie na znaczących, których znaczone znikaja. Przezroczystość znaczenia staje się nieprzejrzysta, gdy znaki ukazują się jako znaczące"; L. Marin, Zerwania, przerwy i synkopy w przedstawieniu malarskim, przeł. P. Tarasewicz, [w:] tegoż, O przedstawieniu..., s. 445.

${ }^{20} \mathrm{~W}$ sztuce pojęcie to określa zestawienie obok siebie dwóch obrazów, podobnych zarówno pod względem formatu, kompozycji, kolorystyki, jak i tematyki, projektowanych jako para, zajmujacych symetryczne pozycje w całości (dlatego też często spotykamy pendanty w formie dyptyku), ukazujących dwa dopełniające się przedstawienia, np. Jezusa i Maryję, korespondujących małżonków etc. Termin ten funkcjonuje także w znaczeniu ogólniejszym, pozaartystycznym: ekwiwalent, odpowiednik albo uzupełnienie. Stownik języka polskiego PWN definiuje „pendant” jako „rzecz lub pojęcie uzupełniające, tworzacce wraz z innymi harmonijną lub symetryczną całość”; <https://sjp.pwn.pl/sjp/pendant;2571098.html>. Sam termin ma źródłosłów francuski: czasownik pendre, od którego wywodzi się wyraz pendant (polszczyzna przejęła go dokładnie w takiej formie), pochodzi od łac. pendeo, pendēre - „wisieć”; co ciekawe, istnieje też łac. czasownik pendo, pendere, który znaczy „ważyć”, i zdaniem niektórych to z nim trzeba wiązać etymologię słowa pendant, jako że w formie tej chodzi właśnie o wagę, scil. jedna strona równoważy druga, dlatego mogą być zestawione i sobie odpowiadaja. 
artefakt jest symetryczny względem opisującego go tekstu, który dopiero razem z nim stanowi kompletną całość ${ }^{21}$.

Co więcej, w przypadku przywołania przez tekst literacki (powieść, opowiadanie $^{22}$ ) realnego dzieła sztuki należącego do świata pozaliterackiego zachodzi dość zadziwiające zjawisko: słowa dotyczące dzieła przestaja być quasi-sądami, jak otaczające je w tekście wypowiedzi (czy to opis, czy opowiadanie, czy słowa bohaterów), a stają się naturalnymi illokucjami/ aktami mowy, traktowanymi jak głos historyka, krytyka sztuki albo eseisty piszącego o sztuce, albo po prostu jako „prawdziwa” (a nie „udawana”, literacka) wypowiedź na temat konkretnego artefaktu ${ }^{23}$. Dzieje się tak, jak mi się wydaje, za sprawą następującego mechanizmu. Otóż dzieło sztuki w rzeczywistym, dostępnym nam empirycznie świecie ma status jeśli nie słabszy ontologicznie, to przynajmniej inny niż przedmioty realne. Natomiast to samo dzieło sztuki w świecie fikcji artystycznej (czy to wyrażonej słowem, czy inaczej, np. obrazem - przez obraz w obrazie) staje się bardziej realne niż całe ich otoczenie, gdyż paradoksalnie silniej identyfikujemy je

${ }^{21}$ Skojarzenie z formą pendanta jest nie od rzeczy, o czym przekonuje spostrzeżenie filolog klasycznej, uznanej znawczyni ekfrazy starożytnej, Shadi Bartsch. Zwraca ona uwagę na opis przedstawienia malarskiego, na jaki natyka się narrator w antycznym romansie greckim z II wieku - Dafnis i Chloe Longosa. Narracja, która następuje po umieszczonym na początku opisie, nie tylko jest powodowana przez obraz (który, jeśli otwiera utwór literacki, zapowiada jego temat, na zasadzie figury prolepsis, i komunikuje znaczenie alegoryczne), lecz także tworzy literacki ekwiwalent artefaktu i przedłużoną ekfrazę dzieła sztuki. Bartsch cytuje tu słowa narratora, który spojrzał na dzieło i powiedział: „I conceived a strong desire to compose a literary pendant to that peinted picture. Upon inquiry I found an interpreter of the picture, and I have carefully set the story out in four books" (wyróżnienie moje); S. Bartsch, Decoding the Ancient Novel. The Reader and the Role of Description in Heliodorus and Achilles Tatius, Princeton 1989, s. 41. Bartsch przywołuje tu tłumaczenie z greki na angielski Mosesa Hadasa.

${ }^{22} \mathrm{~W}$ wierszu mamy często do czynienia z rodzajem pozaczasowej obserwacji i refleksji w ujęciu dzieła sztuki; z kolei w dzienniku, pamiętniku, autobiografii i esejach świat przedstawiony jest w założeniu rzeczywistością realną - choć odtwarzaną w słowie, to zarazem pozasłowną i do tego rzeczywistego świata należy też dany artefakt; w opowiadaniu i powieści mamy zaś jakościowo inną sytuację - w fikcyjną fabułę włączone zostają prawdziwe elementy (dzieło sztuki).

${ }^{23}$ Danuta Ulicka pisze o mimologicznej koncepcji literatury, o koncepcji quasi-sądów Ingardena, która zestawią z rozumieniem wypowiedzi literackiej przez analityczną filozofią języka i konkluduje, że oba podejścia nakładają się na siebie i podają taką samą charakterystykę tejże wypowiedzi: „Zbudowana z quasi-sądów/będąca zbiorem quasi-illokucji, jest ona wypowiedzią stwarzającą przedmiot, o którym na pozór powiadamia, wypowiedzią więc pozbawioną referencji do przedmiotów autonomicznych wobec świadomości i/albo języka. Jako taka nie podlega ona logicznej ocenie"; D. Ulicka, Granice literatury i pogranicza literaturoznawstwa. Fenomenologia Romana Ingardena $w$ świetle filozofii lingwistycznej, Warszawa 1999, s. 202. Do wypowiedzi językowych dotyczacych dzieła sztuki nie stosowałoby się, w moim ujęciu, określenie, że naśladują wypowiedzi na temat sztuki, gdyż one same byłyby takimi wypowiedziami, a nadto nie byłyby pozbawione odniesienia do rzeczywistości pozajęzykowej. 
z rzeczywistością. Wynika to z jego wyjątkowej jednostkowości w znaczeniu bycia jedynym desygnatem, do którego może odnosić przedstawienie (językowe, jak w ekfrazie, albo wizualne, jak w formie obrazu w obrazie), a zarazem bycia wybitnym dziełem sztuki.

\section{Reprezentacja jako zapośredniczanie}

Można wskazać jeszcze jeden aspekt reprezentacji, tak jak zrobił to Louis Marin, który w tekście z 1986 roku pisał: „reprezentacja prezentuje siebie, reprezentując coś innego"24, a w artykule z 1988 roku konstatował:

[...] przedstawiać oznacza przedstawiać się, przedstawiajacc coś, i każde przedstawienie, każdy znak lub proces przedstawieniowy ma podwójny wymiar (wymiar refleksyjny - przedstawiać się, wymiar przejściowy - przedstawiać coś) i podwójny efekt: podmiotu i przedmiotu. Współcześnie semantycy i pragmatycy nazwąje, i nie jest to wcale przypadek, nieprzezroczystością i przezroczystością ${ }^{25}$.

W takim ujęciu ekfraza, rozumiana ogólnie jako tekst reprezentujący dzieło sztuki, sama siebie prezentuje, ujawniając swoje właściwości. Tę samą myśl wypowiada Markowski, kiedy mówi o ekfrazie, że jak każda reprezentacja „z jednej strony zmierza do unaocznienia przedmiotu (ukazanie przedmiotu opisu), z drugiej zaś robi wszystko, by na plan pierwszy wysunaćc sposób jego prezentacji (narrację lub opis)" 26 , reprezentuje więc to, co nieobecne, a autoprezentuje to, co obecne. Mamy więc przedmiot odniesienia i, jak ujmuje to Markowski, przezroczyste wskazywanie, demonstrowanie tego przedmiotu (i tu chyba można dodać: w postaci jego konceptualizacji pojęciowej i wyobraźniowej, jako idei), a też nieprzezroczyste opisywanie go i opowiadanie o nim, skupienie uwagi przez przekaz słowny na sobie. Zatem,

${ }^{24}$ L. Marin, Figury recepcji $w$ nowożytnym przedstawieniu malarskim, przeł. P. Tarasewicz, [w:] tegoż, O przedstawieniu..., s. 374.

${ }^{25}$ Tenże, Mimesis i opis..., s. 300.

${ }^{26}$ M.P. Markowski, Pragnienie obecności..., s. 13. Dodaje: „Być może nie powstałaby ekphrasis, gdyby nie iluzja przezroczystości znaków językowych [...] [to wiąże się z uobecnianiem, R.S.], ale też nie powstałaby, gdyby świadomość ich nieprzezroczystości, umożliwiająca pisanie [to kwestia zastępowania, R.S.]"; tamże. Cały czas powracają więc dwie twarze reprezentacji, czasem interpretowane jako występujące jednocześnie w danej reprezentacji, czasem jako osobne typy reprezentacji. Analogiczną obserwację formułuje Grzegorz Jankowicz: „Gdyby opis zrównał się z obrazem, gdyby to, co przedstawiane, ustapiło miejsca przedstawianemu, gdyby to, co pozajęzykowe, ontologicznie zmieszało się z samym językiem, medium ekfrastyczne nie byłoby potrzebne. [...] pisarze pragną przełamać barierę języka, znieść różnicę między medium dyskursywnym i obrazowym, ale jednocześnie wiedza, że zanik tej różnicy byłby kresem samej ekfrazy"; G. Jankowicz, Nieobecna ekfraza, [w:] Kulturowe wizualizacje doświadczenia, pod red. W. Boleckiego i A. Dziadka, Warszawa 2010, s. 211. 
z jednej strony, można mówić o dominacji słowa, o służebnej pozycji sztuki, jako że ekfraza istnieje kosztem danego artefaktu - przetwarza go na swój sposób i swoje potrzeby, utrwala w innym medium. Tak ujmuje ekfrazę na przykład Peter Wagner, kiedy pisze o jej Janusowym obliczu: ,jako forma mimesis prezentuje się paradoksalnie, jako że obiecuje oddać głos ponoć milczacym obrazom, a zarazem próbuje pokonać moc obrazu przez jego przetransformowanie i opisanie" ${ }^{27}$. Z drugiej jednak strony, dzieło sztuki uzyskuje przez to istnienie $\mathrm{w}$ innym wymiarze, $\mathrm{w}$ odmiennym materiale i formie, więc $\mathrm{w}$ pewnym sensie dokonuje ekspansji, przetransponowane na tekst albo fragmentarycznie w niego właczone.

Z tym wiąże się kolejna kwestia. Ekfraza apeluje do wyobraźni odbiorcy i zdolności mentalnej wizualizacji ewokowanych w opisie scen. Strategia ekfrazy polega bowiem na tym, że odbiorca zostaje skonfrontowany z perswazyjnością tekstu i siłą swojej imaginacji, gdyż sam język nie potrafi uczynić rzeczy widzialna, może najwyżej na nią wskazać i próbować ją opisać. Język zapośrednicza reprezentowane przedstawienie malarskie przez sam fakt, że operuje innymi znakami, że stanowi inne medium wyrazu - reprezentacja dzieła sztuki w tekście nie jest reprodukcja kopia ani powtórzeniem, ale próbą oddania w innej materii semantyki i syntaktyki wizualnego wzorca, a także jego odziaływania na piszącego odbiorcę. Jak twierdzi amerykański filozof i krytyk David Carrier: „Znamy sztukę bezpośrednio, ale pisanie narzuca zwerbalizowany sposób myślenia o owych wizualnych artefaktach. Myślenie wizualne jest strukturowane werbalnie przez retorykę piania o sztuce" 28 . Nasze patrzenie na obraz nie obywa się bez myślenia o obrazie, a to z kolei nie jest wolne od językowego ujmowania świata. Co więcej, każda wypowiedź wyrażająca jednostkowe postrzeganie i przeżywanie dzieła będzie specyficznie ujmować dzieło - w ramę perspektywy mentalnej i stylistycznej indywidualności języka danego piszącego. Dodatkowo samo przedstawienie malarskie zapośrednicza. Nie jest bowiem po prostu wycinkiem realnego świata, ale stanowi utrwalenie pewnej wynikającej z patrzenia interpretacji świata zewnętrznego, jego strukturyzowania i nadawania znaczenia określonym jego składnikom; jest

${ }^{27}$ P. Wagner, Ekphrasis, iconotexts, and intermediality - the state(s) of the art(s), [w:] Icons, Texts, Iconotexts. Essays on Ekphrasis and Intermediality, ed. by P. Wagner, Berlin-New York 1996, s. 13. Grant F. Scott przedkłada podobną myśl; uważa, że ekfrazy często dążą do zawłaszczenia dzieła sztuki, zamiast je tłumaczyć, przejmują je w posiadane, a wobec tego ekfraza może jawić się jako forma eksploatująca dzieło sztuki, demonstrująca dominację i siłę językowej wypowiedzi; G.F. Scott, The rhetoric of dilation: ekphrasis and ideology, „Word \& Image" 1991, Vol. 7, No. 4, s. 302.

${ }^{28}$ D. Carrier, Writing about Visual Art, New York 2003, s. 14. Nauka o sztuce, klasyczne analizy i interpretacje historyków sztuki, a także krytyka artystyczna narzucają nam pewne wzorce, pojęcia, problemy formalne i treściowe. 
zapisem widzenia zmediatyzowanego przez przyjęty przez postrzegającego punkt widzenia ${ }^{29}$.

Subiektywizm, nieodłączny przedstawianiu i malarskiemu, i tekstowe$\mathrm{mu}$, wynika z samego procesu postrzegania (niejednorodnego i nieobiektywnego), z konceptualizowania zagadnień oraz ze sposobu ekspresji - z tego jak ostatecznie zostaje oddane to, co stanowi temat patrzenia i namysłu. Obraz danej rzeczy (tak malarski, jak językowy), aby być obrazem, nie może być po prostu kopią tej rzeczy, gdyż celem nie jest przezroczyste odwzorowywanie, podwajanie ani zastępowanie, ale reprezentowanie, co zakłada $\mathrm{z}$ jednej strony zachowanie podobieństwa z tym, co przedstawiane, z drugiej - wprowadzenie różnicy ${ }^{30}$, z jednej - uobecnienie oryginału, z drugiej jego ekwiwalentyzację w innej formie, z jednej - wskazywanie na obiekt źródłowy, z drugiej - pokazywanie siebie. Wobec tego tak przedstawienia malarskie, jak teksty na ich temat zapośredniczaja, przetwarzają rzeczywistość w sobie właściwy sposób, a ponieważ dzieło plastyczne jest wynikiem zapośredniczania i subiektywizacji obrazowania, jego reprezentacja za pomocą słów będzie zapośredniczeniem zapośredniczenia i subiektywizacja subiektywizacji.

Zatem przejście od obrazu do słowa (w ekfrazie), dokonywane przez opowiadającego i przyjmowane przez odbiorcę, nie jest przezroczystym, mechanicznym procesem ${ }^{31}$. Translacja tego, co widzialne, i samego doświadczenia

${ }^{29}$ Obcujemy de facto $\mathrm{w}$ artefakcie $\mathrm{z}$ pewną interpretacja, obarczoną indywidualnościa spojrzenia patrzącego podmiotu, przefiltrowaną przez tradycję, kulturę, moment historyczny, estetykę i język, w którym zadomowiony jest ten, który tworzy, a też przez jego wiedzę i wrażliwość. O tym, że „sens odbioru całości zależy od nawyku widzenia”, pisze między innymi Meyer Schapiro w tekście Niektóre problemy semiotyki sztuk plastycznych: pole i nośniki znaków obrazowych, tłum. E. König-Krasińska, [w:] Pojęcia, problemy, metody wspótczesnej nauki o sztuce, wybrał, przekłady przejrzał, wstępem opatrzył J. Białostocki, Warszawa 1976, s. 280-301.

${ }^{30}$ Por. M.P. Markowski, Wzór i odwzorowanie, [w:] tegoż, Pragnienie obecności..., s. 3-51.

${ }^{31} \mathrm{Na}$ subiektywny charakter tworzenia obrazów rzeczywistości (tego, co widzimy - widoków, i tego, co widzimy oczyma wyobraźni - wizji) jako na proces właściwy percepcji wzrokowej zwraca uwagę między innymi Elżbieta Tabakowska, przywołując klasyczną pozycję Rudolfa Arnheima z 1954 roku - Art and Visual Perception: A Psychology of the Creative Eye (Sztuka i percepcja wzrokowa. Psychologia twórczego oka, przeł. J. Mach, Warszawa 1978). Ów subiektywizm, jak podkreślają kognitywiści, widoczny jest też w systemie językowym, jako że wynika z tego, jak tworzymy obrazy świata - od percepcji (widoku), przez koncepcję (wizję), po ekspresję (odbicie i opis). Por. E. Tabakowska, Między obrazem a tekstem, czyli o przektadzie intersemiotycznym, [w:] Między obrazem a tekstem, pod red. A. Kwiatkowskiej, J. Jarniewicza, Łódź 2009, s. 37-47. Subiektywizm wiąże się z dokonywaniem różnych transformacji względem wyjściowego materiału (nie chodzi tylko o stratę informacji, ale też np. o dodawanie informacji). Nigdy obraz jakiegoś przedmiotu nie będzie tym przedmiotem (co oczywiste), ale też nie będzie go w pełni reprezentować: „ogląd obrazu-widoku nie daje obiektywnego obrazu-wizji tego obrazu-widoku i nie może prowadzić do powstania obiektywnego 
wizualnego na słowa rodzi wszelako jeszcze inne pytania, dotyczące kontekstowości widzenia i pisania: czy ten, kto opisuje/opowiada, zdaje relację z tego, co właśnie widzi (bazuje na bezpośredniości percepcji), czy też z tego, co kiedyś widział i co sobie przypomina (przez pośrednictwo pamięci), a ponadto, czy odnosi się do oryginału, czy do reprodukcji. Michael Baxandall zwracał uwagę właśnie na wielką różnicę między wyjaśnieniem czynionym przed obrazem a opisem odwołującym się do pamięci danego obrazu, a także między obcowaniem $\mathrm{z}$ oryginałem a kontaktem tylko z reprodukcja ${ }^{32}$. Dodatkowo istotne okazują się dalsze kwestie, mające wpływ na sposób widzenia dzieła i jego opisu: czy autor opisuje to, co widział, czy raczej to, jak widział; w jakich okolicznościach oglądał dzieło; czy opowieść o obrazie jest opisem i wyjaśnieniem czy arbitralną interpretacja, wiernym przekładem czy swobodną wariacją na temat dzieła; czy głównym celem jest opowiedzenie o obrazie czy o sobie, a może funkcja impresywna, wywarcie wpływu na czytelnika (ujęcie go kunsztownym językiem, błyskotliwymi spostrzeżeniami bądź płynnością sugestywnej opowieści o martwym przedmiocie).

Istotny jest bowiem jeszcze jeden aspekt: znaczenie pragmatycznej relacji między przekazem (i wizualnym, i werbalnym) a odbiorca, tj. recepcji dzieła. W przypadku jest to najpierw uwarunkowana kontekstowo (fizycznie, sytuacyjnie, społecznie, kulturowo) recepcja obrazu przez widza, który staje się piszącym, potem zaś recepcja tekstu o obrazie przez czytelnika. $\mathrm{W}$ pewnym sensie stykamy się tu więc z dwiema płaszczyznami tworzenia i odbioru: dzieło sztuki i następujący po nim tekst, a także oglądający to dzieło (który staje się piszącym o nim autorem) i czytający ekfrazę (który staje się oglądającym jej wizualny wzorzec). Zwracają na to uwagę także badacze ekfrazy. Mitchell podkreśla, że w przypadku ekfrazy nie chodzi tylko o relację podmiotu (piszącego) do przedmiotu (dzieła sztuki), ale też o relację podmiotu (mówiącego przez dany tekst o dziele sztuki) do odbior-

obrazu-odbicia lub obrazu-opisu” - wobec tego każdy przekład, w tym przekład intersemiotyczny, jest „subiektywną interpretacja”; tamże, s. 39, 42.

${ }^{32}$ M. Baxandall, Patterns of Intention. On the Historical Explanation of Pictures, New Haven-London 1985, s. 10. Jaś Elsner uważa, że reprodukcja dzieła sztuki sama jest wizualna ekfraza, rezultatem interpretacji, wyboru, ustawienia, okoliczności; J. Elsner, Art History as Ekphrasis, „Art History” 2010, Vol. 33, Iss. 1, s. 13. Już André Malraux w swoim Muzeum wyobraźni z 1947 roku zwracał uwagę na znaczenie fotografii artefaktów - fotografii, które mogą różnie kadrować dzieło, wydzielać z niego detale, a jako gotowe reprodukcje dodatkowo zmieniają światło, kolory i - co trywialne, ale mające ważkie znaczenie dla patrzącego - samą skalę dzieła. Dlatego Malraux mówi o „twórczości z fotografii”, o wykorzystaniu „ekspresywnego detalu” w albumach, o „prywatnych fototekach” jako swoistych kolekcjach stanowiących zarazem zapis indywidualnego widzenia wybranych obiektów artystycznych. Por. A. Malraux, Muzeum wyobraźni (fragmenty), przekład A. Dziadek, [w:] Muzeum sztuki. Antologia, red. M. Popczyk, Kraków 2005, s. 185-210 oraz komentarz do tegoż tekstu: A. Dziadek, Muzeum nowoczesności André Malraux, [w:] tamże, s. 211-219. 
cy. Amerykański teoretyk pisze o trójkątnej relacji i dwóch obcościach/ innościach (othernesses), między którymi tworzy się ekfraza: 1) konwersja z reprezentacji wizualnej na reprezentację werbalną i 2) rekonwersja werbalnej reprezentacji na wizualny przedmiot, dokonująca się w odbiorze czytelnika $^{33}$. Podobne obserwacje formułuje Susan Harrow, która podkreśla, że na ekfrazę składają się przynajmniej dwa procesy: jeden po stronie piszacego, drugi po stronie odbiorcy:

ekfraza nie jest jednym procesem, ale (co najmniej) dwoma: dokonywany przez pisarza przekład percepcyjnego (zwizualizowanego) albo zapamiętanego świata na medium werbalne pobudza pracę czytelnika, który musi ponownie przełożyć [całość] i przekształcić pierwotny akt postrzegania (i jego transformację) $w w y$ obrażony akt postrzegania ${ }^{34}$.

Cały proces można przedstawić następująco. Istniejący obraz (O1) piszący konwertuje na słowo w subiektywny i indywidualny sposób, a następnie odbiorca na podstawie tekstu dokonuje rekonwersji, a właściwie drugiej konwersji, gdyż w wyniku procesu przetworzenia obrazu na słowo otrzymujemy obraz $(\mathrm{O} 2)$ będący wizja piszącego. W konsekwencji mamy dany obraz (O2) ucieleśniający przetworzenie w wyniku komentowania, objaśniania, interpretowania dzieła sztuki przez piszącego (co ma związek z fizjologią i subiektywnością widzenia, a także ze świadomymi i celowymi zabiegami patrzącego autora). Selektywnie wybiera on albo podkreśla te elementy dzieła, które wzmacniają jego interpretację, jego odczytanie - decyduje, na które motywy albo składniki kompozycji wskazać, jakie aspekty treściowe albo techniczne wydobyć etc. ${ }^{35}$. Odbiorca ów sposób widzenia artefaktu dany przez piszącego dodatkowo zapośrednicza, mamy więc jeszcze obraz (03) przeformowany przez odbiorcę, który interpretuje to, co czyta; wizję piszącego (O2) porównuje z dziełem sztuki (O1), a całość konfrontacji przefiltrowuje dodatkowo przez swoją wrażliwość, upodobania czy znajomość materii, a w rezultacie tworzy swoisty wariant pierwotnego wizualnego modelu. Na stworzenie obrazu (O3), obok doświadczania dzieła przez autora tekstu i odbiorcę, składają się nadto istniejące komentarze historyków sztuki, krytyków, eseistów, poetów, pisarzy. Jak bowiem spostrzega David

${ }^{33}$ W.J.T. Mitchell, Ekphrasis and the Other..., s. 164.

${ }^{34}$ S. Harrow, New ekphrastic poetics, „French Studies” 2010, Vol. LXIV, No. 3, s. 263.

35 Jako wyraz indywidualnego doświadczenia wynikającego z osobistej konfrontacji z dziełem sztuki widział ekfrazę już Leo Spitzer, uważany za jednego z pierwszych teoretyków piszacych w XX wieku o ekfrazie nie z perspektywy filologii klasycznej; pisał tak o Odzie do urny greckiej Keatsa: „The ekphrasis, the description of an object d'art by the medium of the word, has here developed into an account of an exemplary experience felt by the poet confronted with an ancient work of art"; L. Spitzer, The "Ode on a Grecian Urn" or content vs. metagrammar, „Comparative Literature” 1955, Vol. 7, No. 3, s. 218. 
Carrier: „kiedy wiele się pisało o sztuce, nasze doświadczanie sztuki jest przefiltrowane przez książkowe odniesienia" ${ }^{36}$. Doznajemy dzieła w podzielony sposób - bezpośrednio niewinnym okiem, zgodnie z koncepcją Johna Ruskina ${ }^{37}$, a zarazem $\mathrm{z}$ bagażem wiedzy, schematów i uprzedzeń poznawczych, wiążąc artefakt z uniwersum tekstów kultury i rzeczywistością pozaartystyczna, przefiltrowanych przez indywidualne doświadczenia i asocjacje. Obraz stanowiący przedmiot postrzegania, następnie przetworzony w opisie, a wreszcie odtworzony w procesie lektury, jest więc zapośredniczony zarówno przez język, jak i przez szeroko rozumiane widzenie (patrzenie, rozumienie, interpretowanie). Mediatyzuje odbiorca dzieła wizualnego, który staje się piszącym autorem, a do lektury nieprzezroczystego tekstu ekfrazy, a poprzez niego i lektury obrazu, przystępuje czytelnik, który dodaje jeszcze jedno piętro do konstrukcji zapośredniczania.

\section{Perspektywa translatologii}

Trzeba wreszcie zauważyć, że pisząc o ekfrazach, czyli tekstach przywołujących dzieła sztuki, a więc takich, które można zakwalifikować jako przykłady przekładu intersemiotycznego, nie sposób nie odnieść się do translatologii. De facto bowiem konfrontujemy się w takim przypadku z rodzajem translacji, próba przetłumaczenia, przeniesienia tekstu wizualnego na tekst werbalny. Chodzi tu więc o rozszerzoną koncepcję przekładu, kiedy dotyczy on także werbalnych transpozycji obrazów ${ }^{38}$. Konsekwencja zastosowania modelu semiotycznego w analizie tego, co nazywamy tekstami kultury, jest założenie, że nie tylko sztuki werbalne, ale i wizualne posługują się znakami, że jedne i drugie możemy czytać, że są tekstami rozwijającymi się w czasie

${ }^{36}$ D. Carrier, Writing about visual art..., s. 22.

${ }^{37}$ Por. J. Ruskin, Niewinne oko. Szkice o sztuce, wybór i przekł. J. Szczuka, wstęp R. Kasperowicz, Gdańsk 2011.

${ }^{38} \mathrm{Z}$ translacją wiążą się nie tylko zagadnienia językoznawcze (odpowiedniość lingwistyczna) i literaturoznawcze (gatunek, konwencja artystyczna), ale i dotyczące kontekstu kulturowego, strategii odbioru, przetransponowania (przeformułowania) z kultury źródłowej do kultury docelowej. Nie będę tu zagłębiać się w badania nad przekładem, poszczególne teorie i zwroty, towarzyszące im metodologie i ideologie. Problematyce tej towarzyszy obszerna literatura, por. między innymi omawiające kluczowe zagadnienia traduktologiczne pozycje: L. Venuti, The Translator's Invisibility. A History of Translation, London-New York 1995; Wspótczesne teorie przektadu. Antologia, pod red. P. Bukowskiego i M. Heydel, Kraków 2009; tłumaczenia zebrane w rozdziale Komparatystyka i/jako translacja, [w:] Niewspótmierność. Perspektywy nowoczesnej komparatystyki. Antologia, pod red. T. Bilczewskiego, Kraków 2010; Kultura w stanie przekładu: translatologia - komparatystyka - transkulturowość, pod red. W. Boleckiego i E. Kraskowskiej, Warszawa 2012. 
(lektura wymaga czasu ${ }^{39}$ ). Obie formy chcą być uchwytne umysłem, choć zarazem bądź (jak obraz) prezentują się w przestrzeni i są od razu pojmowalne zmysłami, jako że zbudowane ze znaków naturalnych (będących wizualnym substytutem dla swojego referenta), bądź (jak ekfraza) chcą apelować także do naszej wyobraźni i zdolności wizualizacji.

Badacze zadają pytanie o przekładalność znaków należących do różnych systemów znakowych, o relację tekstu końcowego do tekstu wyjściowego, o to, na jakich poziomach zachodzi, jeśli w ogóle, ekwiwalencja tych tekstów źródłowego i docelowego; niektórzy uważaja, że taki przekład jest możliwy, inni - że tylko częściowo, jeszcze inni - że w ogóle nie ${ }^{40}$. W moim przekonaniu możliwa jest swoista transpozycja wizualnego obiektu artystycznego na słowo, tak na gruncie historii sztuki (o czym zaświadcza choćby metoda analizy ikonologicznej Panofskiego, będąca swoistą translacją kodów semiotycznych ${ }^{41}$ ), jak pisarstwa o sztuce (krytycznego, eseistycznego) i literatury (proza i wiersz). Podobnie widzi tę kwestię wielu badaczy. Znaczenie opisu w funkcji szeroko pojętego przepisywania danego dzieła sztuki podkreśla Leo H. Hoek ${ }^{42}$. Badacz widzi twórczość werbalną i wizualną jako analogiczne

${ }^{39}$ Recepcja zarówno wypowiedzi werbalnej, jak i wizualnej nie następuje momentalnie. W przypadku lektury tekstu wydaje się to oczywiste, ale trzeba pamiętać, że odnosi się to też do odbioru dzieła sztuki. Michael Baxandall twierdzi: „if a picture is simultaneously available in its entirety, looking at a picture is as temporally linear as language"; M. Baxandall, Patterns of intention..., s. 3. Podobnie Hans Holländer, komentujący teorię Lessinga, stwierdza, że „doświadczenie przestrzenne - a tym samym doświadczenie obrazu - ma strukturę czasową. [...] pod tym względem obrazy nie oddziałują na odbiorcę zasadniczo inaczej niż kolejne strony książki"; H. Holländer, Literatura - malarstwo - grafika. Interakcje, funkcje i konkurencja, przeł. K. Lukas, [w:] Ut pictura poesis, pod red. M. Skwary i S. Wysłouch, Gdańsk 2006, s. 191. Stephen Cheeke zwraca zaśs uwagę na towarzyszący patrzeniu proces uchwytywania sensu obrazu i próby jego wykładni, które tak samo potrzebują czasu; S. Cheeke, Writing for Art. The Aesthetics of Ekphrasis, Manchester-New York 2008, s. 23.

${ }^{40}$ Problem ten omawia Seweryna Wysłouch, Ekfraza czy przekład intersemiotyczny?, s. 48-64. Badaczka uważa, że można przełożyć znak z jednego systemu na inny, a "«poziom budulcowy» [materia znaku] nie może stanowić przeszkody w operacjach znaczeniotwórczych i tworzeniu znaczenia, które wynika z relacji między elementami, a nie z substancji, z której zrobione są te elementy"; tamże, s. 52. Wysłouch przekonuje, że przekład odtwarza oryginał w innym materiale, przekształca go i możemy podać reguły owej transformacji intersemiotycznej - odnosi się do wskazanych przez Edwarda Balcerzana w Poetyce przektadu artystycznego czterech operacji retorycznych, „które mają charakter uniwersalny i działają niezależnie od tworzywa: amplifikacja, redukcja, immutacja (przestawienie elementów), substytucja”; tamże, s. 57. Takie stanowisko zajmuje też np. Clüver, który podkreśla, że ekwiwalenty łatwiej znaleźć w przekładzie interlingwalnym, ale nie jest to nieosiagalne w transpozycji intersemiotycznej; C. Clüver, On Intersemiotic Transposition, „Poetics Today” 1989, Vol. 10, No. 1, s. 62.

${ }^{41}$ E. Panofsky, Ikonografia i ikonologia, [w:] tegoż, Studia z historii sztuki, wybrał, oprac. i posłowiem opatrzył J. Białostocki, Warszawa 1971, s. 11-32.

${ }^{42}$ Podaje tu obok siebie szereg terminów używanych przez różnych badaczy: re-writing, Textbearbeitung, inter-semiotic transposition, translation, adaptation, verbal representation; 
praktyki dyskursywne, choć tworzone za pomocą kodów należących do różnych systemów znakowych, do odmiennych form reprezentacji. Te różnice jednak, jak z kolei uważa Mitchell, nie mają zwiazku z przekazywaniem treści, co potrafi i język, i obraz: język może zastapić przedstawienie obrazowe i odwrotnie, ponieważ akty komunikacyjne, w tym opowiadanie oraz opis, nie są właściwe konkretnemu medium. W przekonaniu badacza z semantycznego punktu widzenia (relacjonowania, wyrażania intencji i oddziaływania na odbiorcę) nie ma zasadniczej różnicy między tekstem a obrazem ${ }^{43}$. Podobnie sądzi Peter Wagner, kiedy podkreśla, że słowa i obrazy mają naturę retoryczną i muszą używać znaków, aby wyrazić znaczenie: stanowią odmienne systemy reprezentacji, ale maja podwójny wspólny mianownik - retorykę i znak, tak więc i tekst, i płótno są systemami znaczącymi i konstrukcjami retorycznymi. Z tego wynika postulat traktowania obrazów jako swoistych tekstów, studiowania ich semiotycznej i retorycznej struktury i „czytania” obrazó $\mathrm{w}^{44}$. Analogiczną strategię interpretacyjną przyjmuje Claus Clüver, który włącza ekfrazę w domenę cytowania i re-prezentowania. Intersemiotyczne cytowanie obejmuje jego zdaniem językowe re-prezentacje tekstów kultury skomponowanych w niejęzykowych systemach znakowych. Badacz mówi o intersemiotycznym prze-pisywaniu, będącym dla niego synonimem werbalizacji tekstu niewerbalnego ${ }^{45}$.

Z tym wiążą się kwestie szczegółowe, dotyczące na przykład tego, co dana strategia tłumaczenia i wybory przekładającego (tu: z języka obrazu na język słowa) robią z tekstem wyjściowym (artefaktem): czy przekład pogłębia znaczenie oryginału, ogranicza je, czy po prostu przekazuje, w miarę możliwości wiernie powtarzając. Za tym stoją pytania o to, czy tłumacz prezentuje twórcze, czy odtwórcze podejście do tekstu oryginalnego, czy przekład jest bezpośredni (literalny), czy pośredni (zależny, ale też: prze-

L.H. Hoek, Image and Word: An Exciting Relationship..., „Interactions - The Bulletin of International Association of Word and Image Studies” 1994, No. $12<$ http://iawis.org/interactions-the-bulletin-of-i-a-w-i-s-no-12-april-1994/>. Por. też tom poświęcony przepisywaniu tekstów i przetwarzaniu obrazów: Rewriting Texts, Remaking Images. Interdisciplinary Perspectives (Studies on Themes and Motifs in Literature, vol. 103), ed. by L. Boldt, C. Federici, E. Virgulti, New York 2010.

${ }^{43}$ W.J.T. Mitchell, Ekphrasis and the other..., s. 160.

${ }^{44}$ P. Wagner, Ekphrasis, iconotexts, and intermediality..., s. 34. Jak konstatuje Mieke Bal: „images are also texts precisely because they constitute a network of discursive practices, albeit visually shaped"; M. Bal, Light in Painting: Dis-seminating art history, [w:] Deconstruction and the Visual Arts: Art, Media, Architecture, ed. by P. Brunette, D. Wills, Cambridge 1994, s. 52, przypis 8. Gwoli ścisłości trzeba dodać, że w pewnej perspektywie interpretacyjnej takie podejście odbierane jest jako narzucanie sztuce plastycznej lingwistycznego modelu interpretacji.

${ }^{45}$ C. Clüver, Quotation, enargeia, and the functions of ekphrasis, [w:] Pictures into Words..., s. 45. 
wrotny, to znaczy taki, który zaskakuje, czasami niewyraźny, a czasami wykrzywiajacy), ujmujac tę kwestię w terminach Jeana-Paula Vinay i Jeana Darbelnet ${ }^{46}$. Mamy więc dwie ogólne koncepcje przekładu: tłumaczenie jako „językowy transfer danych” albo jako „oparta na interpretacji i inwencji re-kreacja tekstu" ${ }^{47}$. Wolfram Wilss wykłada to rozróżnienie, przypominajacc Cyceroniańskie rozdzielenie relacji ut interpres (,jako pośrednik”, ,jako rzecznik”, „jako tłumacz”) od relacji ut orator (jako mówca), która dominuje $\mathrm{w}$ debacie na temat roli tłumacza. Chodzi o to, czy powinien on być wierny tekstowi wyjściowemu i tym samym działać w funkcji un interpres, czy też raczej powinien odtworzyć sens tekstu zgodnie z konwencjami epoki i kręgu kulturowego, wziąwszy pod uwagę oczekiwania odbiorców, czyli działać $\mathrm{w}$ roli ut orator $^{48}$. W przypadku ekfrazy zachodzi zazwyczaj w większym stopniu powtarzanie, kopiowanie niż twórcze przeformowanie, ale i tak dochodzi do transformacji (silniejszej niż w procesie przekładów z jednego języka na inny).

${ }^{46}$ Badacze nazywając te dwa rodzaje przekładu odpowiednio direct/literal translation i oblique translation, por. J.-P. Vinay, J. Darbelnet, A Methodology for Translation, trans. by J.C. Sager and M.-J. Hamel, [w:] The Translation Studies Reader, ed. by L. Venuti, London-New York 2000, s. 84. Terminy te przywodzą na myśl łacińskie odróżnienie oratio recta (mowa niezależna, bezpośrednia) i oratio obliqua (mowa pośrednia, zależna). Transponując tekst z języka źródłowego na język docelowy, jak piszą badacze, opieramy się na paralelizmie kategorii (strukturalnym) albo paralelizmie idei (metajęzykowym). Oczywiście różnice strukturalne bądź metajęzykowe między językiem tekstu źródłowego a językiem tekstu docelowego moga wpływać na niemożność zachowania na przykład pewnych cech stylistycznych bez ingerencji w składnię czy leksykę oryginału. Pojawiają się też w tekście docelowym luki, które tłumacz musi wypełnić odpowiadającymi oryginałowi elementami. Wtedy też zachodzi oblique translation. Zgodnie z tą propozycją pożyczki, kalki, literalne tłumaczenia wiążą się z przekładami bezpośrednimi, natomiast transpozycja, modulacja, ekwiwalencja, adaptacja są właściwe oblique translation. Choć zaproponowane przez francuskich badaczy terminy i ich znaczenia są do pewnego stopnia arbitralne i nie dają wyczerpującej i rozłącznej klasyfikacji przypadków, cenne pozostaje ogólniejsze rozróżnienie tłumaczeń direct i oblique.

${ }^{47}$ Por. streszczające problematykę przekładoznawstwa w perspektywie historycznej Wprowadzenie. Przekład-język - literatura, [w:] Wspótczesne teorie przekładu..., s. 5-37 (cytowane sformułowania ze s. 6). W badaniach dotyczacych traduktologii, tak jak i na innych obszarach, nie panuje homogeniczność pojęciowa - rozumienie nawet takich terminów jak translacja i transfer nie jest ugruntowane. Często tłumaczenie rozumie się jako ograniczony rodzaj transferu, powiązany z wymogiem ekwiwalencji albo inwariantywności. Transfer z kolei stanowiłby taką transformację danego tekstu kultury, aby tekst docelowy spełniał określone funkcje dla odbiorców w kulturze docelowej, a więc funkcjonalizm jest tu nadrzędną zasadą (niekiedy mówi się o takim wariancie tekstu jako o adaptacji). Por. S. Göpferich, Transfer and transfer studies, [w:] Handbook of Translation Studies, Vol. 1, ed. by Y.Gambier and L. van Doorslaer, Amsterdam-Philadelphia 2010, s. 374-377.

${ }^{48}$ W. Wilss, Übersetzungswissenschaft: Probleme und Methoden, Stuttgart 1977, s. 30-31. Por. też J. Ziomek, Przektad - rozumienie - interpretacja, [w:] Powinowactwa literatury. Studia $i$ szkice, Warszawa 1980, s. 159-200. 
Zgodnie z ogólną tezą André Lefevere'a ${ }^{49}$ tekst (też w znaczeniu szerokim, np. obraz), jak promienie światła w zjawisku refrakcji, ulega transformacjom przy przejściu z jednego ośrodka językowego (i szerzej: znakowego) i kulturowego do innego, co tym bardziej dotyczy przejścia od dzieła wizualnego do dzieła werbalnego. W wyniku przekładu nie uzyskujemy reprodukcji danego dzieła w innym medium, ale, jak ujął to Tomasz Bilczewski, „swoiste hybrydy”. Nie ma bowiem ścisłej ekwiwalencji między językami (a tym bardziej między różnymi systemami znakowymi, różnymi mediami); języki nie są transparentnym opakowaniem dla sensu ${ }^{50}$, więc translacja to transformacja (przekształcenie, przetworzenie; można powiedzieć: transpozycja - przeniesienie, przestawienie) ${ }^{51}$, a tym samym zapośredniczanie. W przypadku tłumaczenia dzieła sztuki na słowo - translacja nigdy nie zastapi oryginału. Jak ujmuje to historyk sztuki i filolog Jaś Elsner: „deskrypcja nie jest jedynie selektywna; jest (w najlepszym przypadku) paralelnym dziełem sztuki. [...] jakkolwiek dobre by było słowne przybliżenie opisywanego obiektu, nigdy nie zdoła w pełni być tym obiektem lub w pełni go zastapić" ${ }^{52}$. W takim przypadku najlepsze rezultaty poznawcze i estetyczne osiagniemy, jeśli zestawimy ze sobą obraz i tekst, jeśli uzupełnimy lekturę ekfrazy o oglądanie obrazu i będziemy konfrontować ze sobą obie formy wypowiedzi artystycznej. Dzieło sztuki w tak pojętej translacji funkcjonuje jako suplement, na który wskazuje tekst.

Podobnie o tłumaczeniu pisze Lawrence Venuti ${ }^{53}$, który konceptualizuje przekład jako komunikat stanowiący interpretację tekstu źródłowego, a nie jego reprodukcję, a ekfrazę uważa za rodzaj przekładu. Przekonuje, że teorie translacji pozwalają dobrze opisać relację tekstów ekfrastycznych do obrazów stanowiących ich źródło. W przypadku ekfrazy nie mamy bowiem, jak uważa Venuti, do czynienia z prostym transferem formalnego albo semantycznego inwariantu, ale $\mathrm{z}$ relacją hermeneutyczna, z interpretacja, która różnicuje formę i znaczenie tekstu źródłowego - poprzez zastosowanie

${ }^{49}$ Por. A. Lefevere, Translation, Rewriting, and the Manipulation of Literary Fame, London-New York 1992.

${ }^{50}$ T. Bilczewski, Komparatystyka i interpretacja. Nowoczesne badania porównawcze wobec translatologii, Kraków 2010, s. 9, 119.

${ }^{51}$ Bilczewski odnosi się do łac. słów interpretari oraz traducere i transferre oraz ich życia w językach europejskich. Podkreśla zawarte w samym słowie tłumaczenie znaczenie zarówno objaśniania, jak i przekładania, a w przekładaniu widzi „zabieg przeniesienia, przemieszczenie tekstu z jednej rzeczywistości językowo-kulturowej w druga, transponowanie pewnego obrazu świata zapisanego w języku w inną geografię pamięci”; tamże, s. 116.

${ }^{52}$ J. Elsner, Art history as ekphrasis..., s. 12.

${ }^{53}$ L. Venuti, Ekphrasis, translation, critique, „Art in Translation” 2010, Vol. 2, Iss. 2, s. $131-152$. 
interpretanta, formalnego i/lub tematycznego $0^{54}$ - i może przesuwać, usuwać, dodawać, zastępować materiał tekstu wyjściowego, czyli danego dzieła sztuki. W rezultacie następuje transformacja tekstu źródłowego, jako że interpretant pozostaje w relacji do szeroko pojmowanej tradycji kulturowej, a ta różni się od kontekstu towarzyszącego materiałowi źródłowemu (obrazowi), uwikłanemu w specyficzny teoretyczny, krytyczny czy społeczny dyskurs, a także w specyficzny kontekst recepcji. Translacja, a tak samo ekfraza (ta na większą skalę, ze względu na zmianę medium), dekontekstualizuje dany tekst/obraz ze względu na różnice między systemami znakowymi wchodzącymi w interakcje, na uwikłanie każdego z nich w daną sytuację kulturową i moment historyczny, w jakim powstały lub powstaja. Zarazem dokonuje się rekontekstualizacja:

Translacja przepisuje tekst źródłowy w kategoriach zrozumiałych i interesujących dla obiorców, sytuując go w odmiennych wzorcach językowych, w odmiennej tradycji literackiej, w odmiennych wartościach kulturowych, w odmiennych uwarunkowaniach społecznych i często w odmiennym momencie historycznym ${ }^{55}$.

W tym miejscu chciałabym na chwilę zatrzymać się nad kwestiami, o których napomknęłam wcześniej, a które wymagają choć krótkiego komentarza - przekładu intersemiotycznego i funkcji, jakie pełni w nim interpretant. Szczególne znaczenie w badaniach intersemiotycznych ma, także ze względu na terminologię, nieodmiennie przywoływany artykuł Romana Jakobsona On Linguistic Aspects of Translation z 1959 roku (to tu pojawia się pojęcie przekładu intersemiotycznego), w którym mowa o trzech sposobach interpretowania znaku językowego, trzech rodzajach tłumaczenia, $\mathrm{w}$ tym o przekładzie intersemiotycznym (intersemiotic translation), zwanym też transmutacją. Stanowi on ,interpretację znaków językowych za pomocą znaków pozajęzykowych systemów znakowych", w której dokonuje się „transpozycja intersemiotyczna - z jednego systemu znaków na inny” ${ }^{6}$.

${ }^{54}$ Tamże, s. $140-141$.

${ }^{55}$ Tamże, s. 138-139. Na to samo zwrócił uwagę Adam Dziadek, kiedy pisał o badaniach nad interferencją obrazów oraz tekstów i, idąc za Barthes'em rozumiejącym obraz jako tekst do przeczytania i do napisania, proponował ustalenie treści, jakie tekst chce zakomunikować w podwójnym ruchu: „Dekontekstualizacja polegałaby na wyprowadzeniu obrazu z kontekstu utworu, który się do niego odwołuje, i umieszczeniu go w kontekście rodzimym [...]. Zadaniem rekontekstualizacji zaś musiałoby być umieszczenie obrazu - wraz z całym zasobem danych [...] - w kontekście deszyfrowanego utworu"; A. Dziadek, Obrazy i wiersze. $Z$ zagadnień interferencji sztuk w polskiej poezji wspótczesnej, Katowice 2004, s. 21. Por. też A. Dziadek, Rolanda Barthes'a lektury obrazów (oraz to, co dla metodologii z nich wynika), [w:] Intersemiotyczność. Literatura wobec innych sztuk (i odwrotnie), pod red. S. Balbusa, A. Hejmeja, J. Niedźwiedzia, Kraków 2004, s. 53-70.

${ }^{56} \mathrm{R}$. Jakobson, O językoznawczych aspektach przektadu, przeł. L. Pszczołowska, [w:] Wspótczesne teorie przekładu..., s. 44, 49. 
Wydaje się, że można rozszerzyć rozumienie translacji intersemiotycznej i odwrócić kierunek tłumaczenia - mówić o przekładzie intersemiotycznym także wówczas, gdy znaki językowe interpretuja znaki niejęzykowe ${ }^{57}$. Termin stosowałby się do przypadków, w których dochodzi do przekładu (w dowolnym kierunku) między tekstami, należącymi do różnych systemów semiotycznych $^{58}$. Tak też funkcjonuje on w badaniach. Tekst stanowiący transpozycję intersemiotyczną analizowany jest jako system znaków pozwalajacy na konstruowanie znaczenia podobnego do znaczenia, jakie może być stworzone w znakach innego systemu. Zajmujący się tym zagadnieniem Claus Clüver zwraca uwagę na dwie istotne kwestie. Po pierwsze, podkreśla, że najlepiej potrafią docenić wartość przekładu ci, którzy go najmniej potrzebuja, ponieważ tylko w zestawieniu z oryginałem (co wymaga znajomości innego języka, a w przypadku obrazu - innego kodu znakowego) można roz-

${ }^{57}$ Seweryna Wysłouch opowiada się za stosowaniem w odniesieniu do współczesnych tekstów terminu przekład intersemiotyczny, a nie ekfraza. Stawia po stronie ekfrazy opis, prezentację, uobecnienie, mimesis, a po stronie przekładu intersemiotycznego - nawiązanie intertekstualne, reprezentację (,syntetyczny model”), przekład znaków, poetykę niemimetyczna, uogólnienie cech, transformację (zmiana statusu) przedmiotu. Przekład intertekstualny, w odróżnieniu od ekfrazy, miałby pozwalać na opis, który redukuje i syntetyzuje, a jej zdaniem w pracach współczesnych odchodzi się od „właściwej”, klasycznej ekfrazy (uosabianej przez twórczość Filostrata), którą miałby charakteryzować solidny opis: „już nie opis, ale intertekstualność staje się dominantą strukturalną w tych utworach"; S. Wysłouch, Ekfraza czy przekład intersemiotyczny?..., s. 62. Zdaniem badaczki, jak dointerpretowuję jej tezy, prawdziwy opis (taki, który byłby właściwy dla ekfrazy) prezentuje, odnosi do dzieła sztuki (wskazuje na nie), uobecnia, nie zawiera elementów dyskusji z dziełem, nie prowadzi do formułowania własnych opinii czy dzielenia się przemyśleniami ze strony opisującego. Nie znamy jednak takich czystych ekfraz dziś, nie tworzył ich też Filostrat. Ponadto kategorie opisu i intertekstualności nie są rozłączne ani nie dotyczą tego samego poziomu charakterystyki tekstu. Opis to jedna z form podawczych, intertekstualność to zjawisko tekstowe, czy szerzej: kulturowe, pewien zabieg czy technika stosowana w tekstach nie tylko słownych (choć wtedy częściej mówi się o intersemiotyczności). Opis i intertekstualność mogą występować razem, na przykład mamy opisy zawierające odniesienia intertekstualne, tak jak właśnie w ekfrazie. Przeciwstawianie ekfrazy i przekładu intersemiotyczego nie wydaje się uzasadnione, gdyż przekład nie jest alternatywa dla ekfrazy, ale procesem, jaki zachodzi w ekfrazie, charakteryzuje jej powstawanie. Wszak odnosi ona w opisie intersemiotycznie do innego dzieła, daje mniej lub bardziej syntetyzujące, indywidualne i jednostkowe przedstawienie plastycznego wzorca. Zupełnie wiernych i pełnych deskrypcji właściwie nie ma, jak wcześniej pisałam, odbiorca, patrząc, już interpretuje, a to znajduje wyraz w jego ujęciu przedmiotu odniesienia; kwestia wierności naśladownictwa, realizowania ideałów mimesis jest tu więc rozluźniona i dyskusyjna. Ekfraza pokazuje, jak piszący pojmuje i w jaki sposób wyraża dane dzieło, może więc pojawić się też tu interpretacja. Pojęcie przekładu intersemiotycznego opisuje więc raczej pewien ogólny proces, a jednym z jego rezultatów jest ekfraza.

${ }^{58}$ Postuluje to też Elżbieta Tabakowska w tekście Między obrazem a tekstem... Badaczka proponuje rozumienie tego terminu jako przekładu między mediami, ale wówczas chyba trafniejszy byłby termin przektad intermedialny. 
poznać, czego dokonano, i ocenić np. znaczące zniekształcenia lub pominięcia, ujawniające się przy zestawieniu tekstu oryginalnego i tekstu docelowego. Po drugie, badacz kładzie nacisk na fakt, że transpozycje intersemiotyczne sa także tekstami o tworzeniu tekstu, pokazującymi możliwości i ograniczenia inherentne obu systemom znakowym, a także uświadamiającymi różnice w kodach gramatycznych i estetycznych, co najlepiej, jego zdaniem, widać $\mathrm{w}$ konfrontacji przedstawienia obrazowego i opisu (depiction i description) ${ }^{59}$.

Z koncepcja przekładu intersemiotycznego/transpozycji intersemiotycznej wiąże się idea interpretanta. Jak wskazał Markowski, nawiązując do Jakobsona: „zarówno rozumienie znaku, jak i przekład z jednego systemu znakowego na drugi polega na znalezieniu odpowiedniego interpretanta, który pozwoli porównać dwa elementy i nadać im wspólną miarę", dlatego ekwiwalentyzacja, rozumiana jako „znalezienie medium, dzięki któremu to, co pozornie nieporównywalne, może zostać porównane", staje się podstawową strategią badań intersemiotycznych ${ }^{60}$. Trzeba podkreślić, że niewspółmierność kategorii formalnych właściwych dziełom należących do różnych systemów/mediów uniemożliwia znalezienie równoważności między nimi. W translacji, a szczególnie w przekładzie intersemiotycznym, możliwa jest tylko swoista ekwiwalencja - do pewnego stopnia, w pewnych obszarach, uwarunkowana także pragmatycznie. Umożliwić ją ma właśnie interpretanttermin C.S. Peirce'a ${ }^{61}$, zapożyczony i rozwinięty przez Michaela Riffaterre'a czyli forma pośrednicząca, trzeci element każdej operacji semiotycznej, idea obecna w obu dziełach, stanowiąca ich punkt wspólny, pozwalająca na ich powiązanie przez odbiorce $e^{62}$. Interpretant pozwala na stworzenie sensownego przekładu jednego tekstu na inny, ale też na wykonanie ważnego ruchu w procesie lektury i interpretacji danego tekstu (np. będącego ekfraza, która zresztą sama wcześniej odniosła się do jakiegoś interpretanta w translacji danego działa sztuki na materię słowna). Otóż w czasie czytania powinno nastapić przejście z poziomu sensu (ang. meaning, fr. signification - płaszczyzna mimesis; domena sensu powstającego na skutek następstwa słów

${ }^{59}$ C. Clüver, On intersemiotic transposition..., s. 69-70.

${ }^{60}$ M.P. Markowski, O reprezentacji..., s. 299. Polski badacz podaje przy tym szereg innych określeń, które nie są jednak synonimami, ale odnoszą się do różnych przypadków - różnych co do stopnia ekwiwalentyzacji i co do uwikłanych w nią mediów: „transpozycja, transmutacja, interferencja, przekład, ekfraza, adaptacja, interpretacja, homologia, analogia, korespondencja”.

${ }^{61}$ Por. Ch.S. Peirce, Logic as semiotic: the theory of signs, [w:] Semiotics. An Introductory Anthology, ed. by R.E. Innis, Bloomington 1985, s. 4-23.

${ }^{62}$ Przykład Riffaterre'a - dla wiersza Audena Musée des Beaux Arts i obrazu Upadek Ikara Brueghla interpretującym intertekstem jest idea obojętności i niemieckie przysłowie mówiące, że żaden pług nie zostaje zatrzymany przez wzgląd na umierającego człowieka; M. Riffaterre, Textuality. W.H. Auden's „Musée des Beaux Arts”, [w:] Textual Analysis, ed. M.A. Caws, New York 1986, s. 5. 
i kumulacji informacji już w pierwszej, linearnej lekturze tekstu, wymagającej tylko kompetencji językowych i uwzględnienia zwykłej referencjalności języka; to co utwór zdaje się mówić) na poziom znaczenia (ang. significance, fr. signifiance - płaszczyzna semiosis; odnosi się do tekstu rozumianego jako zamknięty zbiór znaków, zunifikowana całość semantyczna, której znaczenie można zrekonstruować dopiero w wyniku ponownej lektury „retrospektywnej”, odcyfrowującej znaczenia słów w kontekście ich związku z uniwersum tekstów; to, co utwór naprawdę mówi). Signification tekstu wiąże się z jego forma nadana przez autora, natomiast signifiance powstaje w wyniku konfrontacji signification z odbiorca, z jego zainteresowaniami, wiedza, sposobem postrzegania etc., to odbiorca bowiem przekształca tekst ${ }^{63}$. Znaczenie (signifiance), w przekonaniu badacza, wydobywane jest w rezultacie głębokiej lektury, która nie jest po prostu recepcją informacji przekazanych przez tekst, ale namysłem odbiorcy nad semiotycznym jego znaczeniem, nad sensem wyłaniającym się zza całości znakowej, jaką jest dana relacja werbalna. $\mathrm{Na}$ poziomie znaczenia następuje transformacja dzieła i to właśnie interpretant, jak uważa Riffaterre, jest pośrednikiem, pozwalającym przejść z pierwszego poziomu rozumienia dzieła na drugi ${ }^{64}$. W przypadku tekstów odnoszaccych do dzieł sztuki to artefakt wizualny jest intertekstem, a interpretantami, pozwalającymi dostrzec głęboki sens tekstu, przejść wymagającą drogę lektury wielopoziomowej, sa idee i motywy, które znalazły swój wyraz w przedstawieniu wizualnym, do których znaczenia odnosi też tekst.

Tak więc ekfraza, mówiąc umownie i skrótowo, wzbogaca tak strukturę, jak treść danej wypowiedzi, wprowadza do globalnego znaczenia kolejne poziomy sensów, kolejne tematy i odcienie interpretacji. Sama stanowi miejsce zagęszczenia zapośredniczania, ale w ten sposób niesie ze sobą warstwy nieprzezroczystości, które moga zostać odsłonięte właśnie w wyniku głębokiej lektury.

${ }^{63}$ Wtedy możemy mówić o signifiance rozumianej jako „une praxis de la transformation par le lecteur"; M. Riffaterre, Sémiotique de la poésie, Paris 1983, s. 25. Swój pomysł Riffaterre rozwijał także w tekście z 1979 roku Sémiotique intertextuelle: l'interprétant, gdzie mówił o zbliżaniu tekstów w procesie lektury. Dokonuje tego czytelnik, któremu narzucaja się analogie między jednym komunikatem werbalnym a innymi (które stają się intertekstem dla pierwszego; kluczowe są dla badacza podobieństwa strukturalne, jako że tekst aktualizuje inwariant intertekstu dzięki konstantom formalnym i semantycznym). Jeśli czyta się tekst, odnosząc się do intertekstu, ale pomijając interpretant, „percypuje się jedynie aluzję, cytat, źródło”; interpretant kształtuje związek między intertekstem a jego „ponownym zapisem”, jakim jest tekst, funkcją intertekstu zaś jest „tworzenie sposobu tego ponownego zapisu i dyktowanie jego reguł odszyfrowywania"; M. Riffaterre, Semiotyka intertekstualna: interpretant, przeł. K. i J. Faliccy, „Pamiętnik Literacki” 1988, z. 1, s. 304, 314.

${ }^{64}$ Jak ują to Adam Dziadek: ,interpretant prowadzi czytelnika w jego lekturze porównawczej”; A. Dziadek, Interpretant - zarys zagadnienia, [w:] Znajomym gościncem. Prace ofiarowane Profesorowi Ireneuszowi Opackiemu, red. T. Sławek, Katowice 1993, s. 219. 


\section{BIBLIOGRAFIA}

Bal M., Light in painting: Dis-seminating art history, [w:] Deconstruction and the Visual Arts: Art, Media, Architecture, ed. by P. Brunette, D. Wills, Cambridge 1994.

Bartsch S., Decoding the Ancient Novel. The Reader and the Role of Description in Heliodorus and Achilles Tatius, Princeton 1989.

Baxandall M., Giotto and the Orators. Humanist Observers of Painting in Italy and the Discovery of Pictorial Composition, Oxford 1971.

Baxandall M., Patterns of Intention. On the Historical Explanation of Pictures, New Haven-London 1985.

Bilczewski T., Komparatystyka i interpretacja. Nowoczesne badania porównawcze wobec translatologii, Kraków 2010.

Boehm G., Opis obrazu. O granicach obrazu i języka, przeł. M. Łukasiewicz, [w:] G. Boehm, O obrazach i widzeniu. Antologia tekstów, red. D. Kołacka, Kraków 2014.

Carrier D., Writing about Visual Art, New York 2003.

Carroll N., Philosophy of Art. A Contemporary Introduction, London-New York 2002.

Cheeke S., Writing for Art. The Aesthetics of Ekphrasis, Manchester-New York 2008.

Clüver C., On intersemiotic transposition, „Poetics Today” 1989, Vol. 10, No. 1, s. 55-90.

Clüver C., Quotation, enargeia, and the functions of ekphrasis, [w:] Pictures into Words. Theoretical and Descriptive Approaches to Ekphrasis, ed. by V. Robillard, E. Jongeneel, Amsterdam 1998.

Dziadek A., Interpretant - zarys zagadnienia, [w:] Znajomym gościncem. Prace ofiarowane Profesorowi Ireneuszowi Opackiemu, red. T. Sławek, Katowice 1993.

Dziadek A., Obrazy i wiersze. Z zagadnień interferencji sztuk w polskiej poezji wspótczesnej, Katowice 2004.

Dziadek A., Rolanda Barthes'a lektury obrazów (oraz to, co dla metodologii z nich wynika), [w:] Intersemiotyczność. Literatura wobec innych sztuk (i odwrotnie), pod red. S. Balbusa, A. Hejmeja, J. Niedźwiedzia, Kraków 2004.

Eco U., Teoria semiotyki, przekł. M. Czerwiński, Kraków 2009.

Eldridge R., An Introduction to the Philosophy of Art, Cambridge 2003.

Elsner J., Art history as ekphrasis, „Art History” 2010, Vol. 33, Iss. 1, s. 11-27.

Glossary of Greek Rhetorical Terms Connected to Methods of Argumentation, Figures And Tropes From Anaximenes to Quintilian, ed. R.D. Anderson Jr., Leuven 2000.

Göpferich S., Transfer and transfer studies, [w:] Handbook of Translation Studies, Vol. 1, ed. by Y. Gambier and L. van Doorslaer, Amsterdam-Philadelphia 2010.

Harrow S., New ekphrastic poetics, „French Studies” 2010, Vol. LXIV, No. 3, s. 255-264.

Heffernan J.A.W., Museum of Words. The Poetics of Ekphrasis from Homer to Ashbery, Chicago 1993.

Hoek L.H., Image and word: An exciting relationship..., „Interactions - The Bulletin of International Association of Word and Image Studies" 1994, No. 12.

Holländer H., Literatura - malarstwo - grafika. Interakcje, funkcje i konkurencja, przeł. K. Lukas, [w:] Ut pictura poesis, pod red. M. Skwary, S. Wysłouch, Gdańsk 2006.

Hollander J., The Gazer's Spirit: Poems Speaking to Silent Works of Art, Chicago 1995. Jankowicz G., Nieobecna ekfraza, [w:] Kulturowe wizualizacje doświadczenia, pod red. W. Boleckiego, A. Dziadka, Warszawa 2010. 
Kultura w stanie przekładu: translatologia - komparatystyka - transkulturowość, pod red. W. Boleckiego i E. Kraskowskiej, Warszawa 2012.

Lefevere A., Translation, Rewriting, and the Manipulation of Literary Fame, LondonNew York 1992.

Malraux A., Muzeum wyobraźni (fragmenty), przekład A. Dziadek, [w:] Muzeum sztuki. Antologia, red. M. Popczyk, Kraków 2005.

Marin L., O przedstawieniu, przekład P. Pieniążek et al., Gdańsk 2011.

Markowski M.P., O reprezentacji, [w:] Kulturowa teoria literatury. Gtówne pojęcia i problemy, red. M.P. Markowski, R. Nycz, Kraków 2010.

Markowski M.P., Pragnienie obecności. Filozofie reprezentacji od Platona do Kartezjusza, Gdańsk 1999.

Mitchell W.J.T., Ekphrasis and the other, [w:] W.J.T. Mitchell, Picture Theory. Essays on Verbal and Visual Representation, Chicago 1994.

Mitchell W.J.T., Representation, [w:] Critical Terms for Literary Study, ed. by F. Lentricchia, T. McLaughlin, Chicago 2010.

Niewspótmierność. Perspektywy nowoczesnej komparatystyki. Antologia, pod red. T. Bilczewskiego, Kraków 2010.

Nycz R., Tezy o mimetyczności, [w:] R. Nycz, Tekstowy świat. Poststrukturalizm a wiedza o literaturze, Warszawa 1993.

Oxford Latin Dictionary, ed. by P.G.W. Glare et al., Oxford 1968.

Panofsky E., Ikonografia i ikonologia, [w:] E. Panofsky, Studia z historii sztuki, wybrał, oprac. i posłowiem opatrzył J. Białostocki, Warszawa 1971.

Peirce Ch.S., Logic as semiotic: The theory of signs, [w:] Semiotics. An Introductory Anthology, ed. by R.E. Innis, Bloomington 1985.

Peirce Ch.S., The icon, index and symbol, [w:] Collected Papers of Charles Sanders Peirce. Vol. II. Element of Logics, ed. by Ch. Hartshorne and P. Weiss, Cambridge (MA) 1931.

Rewriting Texts, Remaking Images. Interdisciplinary Perspectives (Studies on Themes and Motifs in Literature, vol. 103), ed. by L. Boldt, C. Federici, E. Virgulti, New York 2010.

Riffaterre M., L'illusion d'ekphrasis, [w:] La pensée de l'image. Signification et figuration dans le texte et dans la peinture, sous le direction de G. Mathieu-Castellani, Saint-Denis 1994.

Riffaterre M., Sémiotique de la poésie, Paris 1983.

Riffaterre M., Semiotyka intertekstualna: interpretant, przeł. K. i J. Faliccy, „Pamiętnik Literacki” 1988, z. 1, s. 297-314.

Riffaterre M., Textuality. W.H. Auden's „Musée des Beaux Arts”, [w:] Textual Analysis, ed. M.A. Caws, New York 1986.

Riffaterre M., The referential fallacy, „Columbia Review” 1978, Vol. 57, No. 2, s. 21-35.

Ruskin J., Niewinne oko. Szkice o sztuce, wybór i przekł. J. Szczuka, wstęp R. Kasperowicz, Gdańsk 2011.

Salwa M., Iluzja w malarstwie. Próba filozoficznej interpretacji, Kraków 2010.

Schapiro M., Niektóre problemy semiotyki sztuk plastycznych: pole i nośniki znaków obrazowych, tłum. E. König-Krasińska, [w:] Pojęcia, problemy, metody wspótczesnej nauki o sztuce, wybrał, przekłady przejrzał, wstępem opatrzył J. Białostocki, Warszawa 1976. 
Scott G.F., The rhetoric of dilation: ekphrasis and ideology, „Word \& Image” 1991, Vol. 7, No. 4, s. 301-310.

Shapiro G., The absent image: Ekphrasis and the 'infinite relation' of translation', „Journal of Visual Culture" 2007, Vol. 6, No. 1, s. 13-24.

Spitzer L., The “Ode on a Grecian Urn” or content vs. metagrammar, „Comparative Literature" 1955, Vol. 7, No. 3, s. 203-225.

Summers D., Representation, [w:] Critical Terms for Art History, ed. by R.S. Nelson, R. Shiff, Chicago-London 1996.

Tabakowska E., Między obrazem a tekstem, czyli o przektadzie intersemiotycznym, [w:] Między obrazem a tekstem, pod red. A. Kwiatkowskiej, J. Jarniewicza, Łódź 2009.

Ulicka D., Granice literatury i pogranicza literaturoznawstwa. Fenomenologia Romana Ingardena w świetle filozofii lingwistycznej, Warszawa 1999.

Venuti L., Ekphrasis, translation, critique, „Art in Translation” 2010, Vol. 2, Iss. 2, s. $131-152$.

Venuti L., The Translator's Invisibility. A History of Translation, London-New York 1995.

Vinay J.-P., Darbelnet J., A methodology for translation, trans. by J.C. Sager and M.J. Hamel, [w:] The Translation Studies Reader, ed. by L. Venuti, London-New York 2000.

Wagner P., Ekphrasis, iconotexts, and intermediality - the state(s) of the art(s), [w:] Icons, Texts, Iconotexts. Essays on Ekphrasis and Intermediality, ed. by P. Wagner, Berlin-New York 1996.

Wilss W., Übersetzungswissenschaft: Probleme und Methoden, Stuttgart 1977.

Wspótczesne teorie przekładu. Antologia, pod red. P. Bukowskiego, M. Heydel, Kraków 2009.

Wysłouch S., Ekfraza czy przekład intersemiotyczny?, [w:] Ruchome granice literatury. W kregu teorii kulturowej, pod red. S. Wysłouch, B. Przymuszały, Warszawa 2009.

Yacobi T., The ekphrastic model: forms and functions, [w:] Pictures into Words. Theoretical and Descriptive Approaches to Ekphrasis, ed. by V. Robillard, E. Jongeneel, Amsterdam 1998.

Ziomek J., Przekład - rozumienie - interpretacja, [w:] Powinowactwa literatury. Studia i szkice, Warszawa 1980. 